\title{
A NOVELTY OF IMPACT OF SOCIAL MEDIA FROM THE LEGAL PERSPECTIVE
}

\author{
Syarifah Lisa Andriati \\ University of Sumatera Utara \\ syarifah_lisa_andriati@usu.ac.id
}

\begin{abstract}
$A$ long with the development of science and technology, human life is growing dynamically, especially in the field of information and communication. The Cyber Era has produced internet technology and brought a new phenomenon in the area of mass media which also creates new media that is commonly called social media or social networking. Social media is like a two-edged knife. If used wisely, selectively and responsibly, various social networking sites can be useful, but if used irresponsibly, social media can have unfavorable consequences, and even cause legal problems.
\end{abstract}

Keywords: Impact, social media, law

\section{Introduction}

The development of information technology has led to changes in the field of information technology. Through internet technology, there is a change in the pattern of community interaction in the area of mass media that gives birth to a new press called social media or social network such as Facebook, twitter, Instagram, WhatsApp, and so forth. Social media (https:// en.wikipedia.org, 2017) is an online medium, with its users readily participating, sharing and creating content including blogs, social networks, wikis, forums, and virtual worlds. Blogs, social networks, and wikis are the most common form of social media used by people around the world.

The number of internet users in Indonesia steadily increases from year to year. The data obtained from the Internet World Stats shows that the number of internet users in Indonesia in June 2017 has reached 132 million and ranked fourth most in Asia after Japan, Hong Kong, and China. Furthermore, the use of social media such as Facebook in June 2017 has reached 126 million. (Asia Internet World States, 2017)

Andreas Kaplan and Michael Haenlein define social media as "an internet-based application group building on the foundation of Web 2.0 ideology and technology, and which enables the creation and exchange of user-generated content" (2010, page). Andi Hamzah (1990) states that Internet technology brings people to a new civilization, where there is a shift in the reality of life from real activity to the virtual event called cyberspace.

Technological progress is proliferating, ranging from electronic media, transportation, and technology that support community performance. With technology, mobility, and work becomes easier. One of them is the field of Science of Technology and Information (IPTEK) with the network of the interconnected network (internet). Ease of use can help people to discover new things they never knew before. Internet network also influences the development of means of communication. Social media is one example of a means of communication to share information.

Every development must always be accompanied by adverse impacts including technological developments. Agus Raharjo in his book Cybercrime Understanding and Technology Crime Prevention Efforts stated that: "Information and communication technology has also changed the behavior and lifestyle of people globally, and causes the world to become borderless, and bring about change in various areas of life" (2002, page). Social media is an online medium that serves as a means of interaction between individuals and groups in cyberspace. Social media 
users are starting to grow as the population grows. Active internet users worldwide reach 3.17 billion. The average growth of internet users per year is 7.6\%. (http://wearesocial.com, 2015). Mobile users are increasing along with the addition of more modern and new features.

Through the Ministry of Communications and Information Technology on March 25, 2008 the government has issued legal products namely Law Number 11 of 2008 on Information and Electronic Transactions and Law Number 19 of 2016 as the Amendment of Law Number 11 of 2008 on Information and Electronic Transactions (hereinafter abbreviated as UU ITE). One of these laws is meant to control the use of social media. As witnessed in the news media during the era of television, newspapers, and news on the internet have many examples of cases of violations of the Law of Information and Electronic Transactions (UU ITE), not a few civilians who have become victims of legal bondage.

\section{Freedom of Expression in Social Media}

The development of information technology, internet, and social media has an impact on the change of human behavior in socialization and communication. The Internet can facilitate users to exchange information without having to meet each other.

Freedom of expression is a part of human rights. In Indonesia the regulation of freedom of speech is contained in the 1945 Constitution of the Republic of Indonesia (from now on referred to as the 1945 Constitution). In the 1945 Constitution Article, $28 \mathrm{~F}$ states that "Everyone shall have the right to communicate and obtain information to develop his or her personal and social environment, and shall have the right to seek, obtain, possess, store, process and convey information by the use of all available channels" (page).

This article indicates that there is an appreciation to citizens for communicating and obtaining information. Social media is one tool that can be used to describe in cyberspace. In Article 1 of the ITE Law it is mentioned: "Electronic Information is a collection of electronic data, including but not limited to writing, sound, images, maps, designs, photographs, electronic data interchange (EDI), electronic mail, telegram, telex, telecopy or the like, letters, numbers, access codes, symbols or perforations that have been processed that have meaning or can be understood by people who are able to understand it" (page).

In particular, the ITE Act regulates media content, but its character is more of a prohibited media substance. The reason for this material is considered essential to control the need for legal protection against the collection of people who are in the virtual world. Secondly, with the Internet, information can be distributed and forwarded to various parts of the world in an instant and accessible from multiple countries. Distributed content may be derived from subjects that may not be known of their true identity (Joshua, Sitompul, 2012).

One of the negative impacts of information and communication technologies that use the internet is the number of crimes related to internet applications, such as cybercrime, social network account fraud, and defamation. ITE Law becomes the legal umbrella in anticipating the evils of cyberspace (cyber). This ITE Law contains regulations about cyber law covering electronic transactions, electronic evidence, privacy, jurisdiction, intellectual property (Edwin Pardede et al., 2006)

In the ITE Act, there are some articles that contain criminal threats against the subjects of information technology media users. These acts are closely related to the substance or content of the media, which are referred to as prohibited material, among them as follows: 
Tables 1. Content Prohibited Under The ITE Act

\begin{tabular}{|c|c|}
\hline Clause & Contents \\
\hline $\begin{array}{l}\text { Clause } 26 \text { sub- } \\
\text { section } 1\end{array}$ & $\begin{array}{l}\text { Unless otherwise provided by laws and regulations, the use of any information through } \\
\text { electronic media concerning a person's data shall be made with the consent of the } \\
\text { person concerned. }\end{array}$ \\
\hline $\begin{array}{l}\text { Clause } 27 \text { sub- } \\
\text { section (1) }\end{array}$ & $\begin{array}{l}\text { Every person intentionally and without right to distribute and transmit and make acces- } \\
\text { sible Electronic Information and electronic documents that have content that violates } \\
\text { the morals. }\end{array}$ \\
\hline $\begin{array}{l}\text { Clause } 27 \text { Sub- } \\
\text { section }(2)\end{array}$ & $\begin{array}{l}\text { Any person knowingly and without the right to distribute and transmit and make ac- } \\
\text { cessible Electronic Information and electronic documents that have a gambling charge. }\end{array}$ \\
\hline $\begin{array}{l}\text { Clause } 27 \mathrm{Sub}- \\
\text { section }(3)\end{array}$ & $\begin{array}{l}\text { Every person intentionally and without the right to distribute and transmit and make } \\
\text { accessible Electronic Information and electronic documents that have defamation and } \\
\text { defamation. }\end{array}$ \\
\hline $\begin{array}{l}\text { Clause } 27 \text { Sub- } \\
\text { section (4) }\end{array}$ & $\begin{array}{l}\text { Every person intentionally and without the right to distribute and transmit and make } \\
\text { accessible Electronic Information and electronic documents that have a blackmail and } \\
\text { threatening charge. }\end{array}$ \\
\hline $\begin{array}{l}\text { Clause } 28 \text { Sub- } \\
\text { section (1) }\end{array}$ & $\begin{array}{l}\text { Every person intentionally and without right to disseminate information aimed at gener- } \\
\text { ating a sense of hatred or hostility towards specific individuals and community groups } \\
\text { based on ethnicity, religion, race, and intergroup (SARA) }\end{array}$ \\
\hline Clause 29 & $\begin{array}{l}\text { Every person intentionally and without the right to send Electronic Information and } \\
\text { Electronic Documents containing threats of violence or intimidating personally ad- } \\
\text { dressed. }\end{array}$ \\
\hline
\end{tabular}

The articles contain a context of prohibitions against acts that can be categorized as threats to freedom of expression. In the Act of the EU, there is a controversial article because it is often petitioned for judicial review to the Constitutional Court (AP Edi Atmaja, 2014). Soetandyo Wignjosoebroto relates to Article 27 paragraph (3) of the Law on EIT, as for which the source of objection is unclear regarding the subject of the norms of the article: those who make accessible information or those who make an insult and defamation charge reader. Second, the report on humiliation is a chapter which contains a very subjective element of an offense, in contrast to other formulations of crime that are always formulated more objectively, such as theft. Humiliation is still personal because there must be a party who becomes the victim of shame and feel humiliated (Constitutional Court of the Republic of Indonesia, 2009).

Based on the Decision of the Constitutional Court Number 50 / PUU-VI / 2008 and Number 2 / PUU-VII / 2009, the crime of defamation and defamation in the field of Electronic Information and Electronic Transactions is not merely a general offense, but as offense complaints. The affirmation of the attack of claim is intended to be in harmony with the principle of legal certainty and sense of community justice (see explanation of the amendment of UU ITE 2016).

According to Atmakusumah Atraatmadja, the ITE Law does not follow the development of international law. At least fifty countries have transferred rumors of falsehood, humiliation, defamation, from criminal law to civil law. Some states have even wholly abolished the provisions of the bill for the spread of hatred and shame because it is considered difficult to prove or highly subjective (The Constitutional Court of the Republic of Indonesia, 2008.

\section{Cyberbullying in Social Media}

Teenagers are the next generation of Nations that must continue to be fostered in shaping identity and personality by the values that exist in Indonesia. The emergence of various issues related to adolescents both as objects and subjects. Teenagers are one of the most social media users.

The survey shows 1 out of 3 urban dwellers in Indonesia have access to the Internet, of 
which $64 \%$ are teenagers (ages 15-19). Fifty-eight percent of these online activities are used to access social media. Other data were acquired from the calculation www.checkFacebook.com June 2010, it is known that Indonesia occupies the third country in the world with 24,722,360 Facebook users. The site also divides users based on their age that shows teenagers as Facebook's biggest consumers. This section also divides the users based on their age which shows the teenager as the most significant consumer of Facebook with $70.9 \%$ percentage. (Elga Andina, 2010).

The growing use of social media, on the one hand, provides benefits to its users, but on the other hand will have a negative impact if not addressed wisely by the users, especially among adolescents who are still vulnerable to the adverse effects of the use of social media. Lack of knowledge related to legislation results in adolescents becoming perpetrators or victims of the social media.

Moreover, there are people who deliberately use social media to commit criminal acts and make adolescents easy target for their crimes. Also, adolescents should also be careful in posting or disseminating information that might cause hate crimes based on Tribe, Religion, Race, Intergroup and even that contains lies in social media. This is related to the ITE Law which can be subject to legal sanctions for violators.

One form of violence that is often experienced by teenagers in cyberspace is Cyberbullying. Cyberbullying is a term used when a child or teenager received ill treatments such as being humiliated, threatened, humiliated, tortured or targeted by another child or teen using internet technology, digital technology or mobile technology (Anon, 2011). Cyberbullying is the behavior of a person or group who intentionally and repeatedly performs the act of harming others through computer media, cell phones, and other electronic devices (Machsun Rifauddin, 2016).

In other countries, there are many cases of Cyberbullying that end in more serious incidents of suicide. Rahayu (2012) in her research states that Cyberbullying has occurred with a large number $(28 \%)$, but the impact is not so severe. Furthermore, many teenagers do not understand Cyberbullying and the potential impact it can cause.

Cyberbullying is considered valid if the perpetrator and victim are under 18 years of age and is not legally regarded as mature or adult. If one of the parties involved (or both) is over 18 years of age, then the case will be categorized as cybercrime (Potret-Online.Com, August 12, 2013).

Willard in his book Novan Ardy Wiyani entitled Save Our Children From School Bullying (Novan Ardy Wiyani, 2012), mentions the following types of cyberbullying:

a. Flaming, such as sending text messages which contents contain hatred and frontal words. The term "flame" also refers to the words in fiery letter.

b. Harassment (interruption): messages containing interference on email, SMS, or text messages on social networking which is done continuously.

c. Denigration (defamation): the process of indulgence of a person on the internet with the intention of damaging the reputation and good name of the person

d. Impersonation: pretending to be someone else and sending messages or lousy status

e. Outing: spreading other people's secrets, or personal photos of others

f. Trickery (deceit): persuade a person by deception to obtain the person's secrets or own photos

g. Exclusion (expense): deliberately and cruelly removes someone from an online group.

h. Cyber stalking: distracts and defames someone intently to make a big fear of the person

Article on 27 paragraph (3) of the ITE Law states that everyone intentionally and without the right to distribute and transmit and make accessible electronic information and electronic documents that have defamation aspect on it. In addition, Article 17 paragraph (4) of the ITE 
Law states that every person intentionally and without a right to distribute and transmit and make accessible of electronic information and electronic documents that have blackmail and threatening charge.

Cyberbullying in the ITE Act does not contain any light elements. There are only elements of humiliation, defamation, threats, and extortion. While the cyberbullying includes not just parts of shame, slander, risks, and blackmail. Article 27 paragraph (3) and (4) of the ITE Law have not yet related to other elements of cyberbullying, i.e., flaming, harassment, impersonation, outing (spreading others' secrets), trickery (excuses), exclusion, and cyber stalking.

\section{Conclusion.}

The growing use of social media, on the one hand, provides benefits to its users, but on the other hand will also have a negative impact if not addressed wisely by its users, especially among adolescents who are still vulnerable to the adverse effects of the use of social media. Freedom of expression in social media is limited by its content as regulated in the ITE Act. Another impact on the development of social media is Cyberbullying. Cyberbullying done by teenagers in social media is increasingly worrying. Cyberbullying perpetrators are criminally charged under the ITE Act. In order to cope with cyberbullying in social media, it is necessary to take preventive actions through legal counseling and to plant moral values to the students. Social media is like a double-edged knife because on one side it has many benefits, but on the other hand if not used wisely will bring up legal and moral issues.

\section{References}

Anon, (2011). What is Cyberbullying, Exactly?, Stopcyberbullying.org, http://www. stopcyberbullying.org/ what_is_cyberbullying_exactly.html, 2009, Retrieved on August 20 .

Atmaja, AP Edi, (2014). Kedaulatan Negara di Ruang Maya: Kritik UU ITE Dalam Pemikiran Satjipto Rahardjo, Jurnal Opinio Juris. Vol.6 Mei-September 2014, 85-86.

Hamzah, Andi, (1990). Aspek-Aspek Pidana di Bidang Komputer, Sinar Grafika, Jakarta, 43.

http://www.internetworldstats.com/stats3.htm\#asia Accessed on 18 November 2017.

https://id.wikipedia.org, Accessed on 18 Mei 2017.

http://wearesocial.com/uk/special-reports/global-statshotaugust-2015

Kaplan, Andreas M.; Michael Haenlein, (2010). Users of the world, unite! The challenges and opportunities of Social Media. Business Horizons 53(1): 59-68

Mahkamah Konstitusi Republik Indonesia, Putusan Nomor 2/PUU-VII/2009, 57.

Mahkamah Konstitusi Republik Indonesia, Putusan Nomor 50/PUU-VI/2008, 8.

Pardede, Edwin dkk.,(2006). Kebijakan Hukum Pidana dalam Upaya Penegakan Tindak Pidana Pencemaran Nama Baik Melalui Twitter, Diponegoro Law Journal. Volume 5 Nomor 3, 3-4.

Raharjo, Agus, (2002). Cyber Crime Pemahaman Dan Upaya Pencegahan Kejahatan Berteknologi, Bandung, Citra Aditya Bakti, 34.

Rahayu, Elga Andina, (2010). Studi Dampak Negatif Facebook terhadap Remaja di Indonesia. Aspirasi Vol. 1 No.1, 122

Rifauddin, Machsun, (2016). Fenomena Cyberbullying pada Remaja (Studi Analisis Media Sosial Facebook). Jurnal Khizanah Al-Hikmah Vol. 4 No.1 January-June.

Sapty, Florensia, (2012). Cyber bullying sebagai Dampak Negatif Penggunaan Teknologi 
Informasi, Journal of Information System. Volume 8, Issue 1, April, 22.

Sitompul, Josua, (2012). Cyberspace, Cybercrimes, Cyberlaw: Tinjauan Aspek Hukum Pidana, First Edition, PT. Tatanusa, Ciputat, 148-149.

Wiyani, Novan Ardy, (2012). Save Our Children From School Bullying, AR-RUZZ Media, Jogjakarta, 14. 